\title{
Insights on Eastern Hellenistic Historical and Archaeological Material Culture of the Oikoumene: Globalisation and Local Socio-Cultural Identities
}

\author{
Naif Adel Haddad
}

Citation: Haddad, N.A. Insights on Eastern Hellenistic Historical and Archaeological Material Culture of the Oikoumene: Globalisation and Local Socio-Cultural Identities. Heritage 2021, 4, 3307-3330. https:/ / doi.org/10.3390/heritage4040184

Academic Editors: Francesco Soldovieri and Nicola Masini

Received: 24 August 2021

Accepted: 8 October 2021

Published: 12 October 2021

Publisher's Note: MDPI stays neutral with regard to jurisdictional claims in published maps and institutional affiliations.

Copyright: (C) 2021 by the author. Licensee MDPI, Basel, Switzerland. This article is an open access article distributed under the terms and conditions of the Creative Commons Attribution (CC BY) license (https:/ / creativecommons.org/licenses/by/ $4.0 /)$.
Department of Conservation Science, Queen Rania Faculty of Tourism and Heritage, Hashemite University, Zarqa 13115, Jordan; naifh@hu.edu.jo

\begin{abstract}
This paper focuses on the Hellenistic Middle East, especially the age of Ptolemaic Alexandrian and Syrian Seleucid influence. It investigates and clarifies some of the Hellenistic-age historical and archaeological material culture within the Hellenisation and globalisation conceptions. Furthermore, it suggests that by reviewing the context of the local socio-cultural identities in the Hellenistic Oikoumene, mainly based on the lingua franca about local identity and how the local identity was expressed on coinage during Hellenistic times, many related insights issues can be revealed. In addition, it also attempts to discuss and reveal aspects of the cultural sharing achievements in Hellenistic art, architecture, and urban built environment planning. Finally, how did Eastern Hellenistic cities manage to benefit from the process of Hellenistic globalisation and localisation/globalisation while minimising identity risks? The focus is on the transnational socio-cultural and economic area of Ptolemaic Alexandria, the centre of the post-Classical Greek world, and the Syrian Seleucid influence. As an investment, mass migration and the transfer of goods, culture, and ideas increasingly transformed these Middle Eastern cities and shaped their translocal culture conception, local socio-cultural identities, cultural sharing, art and architecture edifice forms, and spatial patterns in the Hellenistic period. One of the main contributions and significance of this study is to continue the dialogue of how non-Greek influence in Hellenistic times impacted an area that has been traditionally seen as unaffected or minimally affected by years under foreign rule. This also sheds new light on some Greco-Macedonian topics not sufficiently debated in the Oikoumene discussion dialogue. These two aspects would furthermore contribute to better understanding and accepting the neglected role of the contribution of non-Greek culture to Greek achievements, as well as how the local non-Greek customs of the indigenous peoples of the Ptolemy and Seleucid kingdoms would affect how they assimilated Greco-Macedonian practices, and how the vision of Alexander the Great and Hellenisation worked in the different territories of these two kingdoms.
\end{abstract}

Keywords: globalisation; identity; localisation; lingua franca; coinage; art; architecture; multicultural community; Hellenisation; Middle East; Hellenised cities; urbanism

1. Alexander the Great and the Particularity of Greco-Macedonian, Hellenism, and the Hellenised World: A Brief Introduction and Scope

There are several reasons why it makes sense to begin this research in understanding the particularity of the Greco-Macedonian excision for making the Hellenistic world, starting with defining and clarifying the meaning of Hellenism and Hellenisation. The Hellenistic world includes the Eastern Mediterranean, Middle East, and Central Asia in Greco-Macedonian domination (formally 330 to $30 \mathrm{BCE}$ ). It was the age when there was a "fusion between the Greek and non-Greek elements in different parts of Asia, North Africa, and Southern Italy" [1] (p. 58). Fernandez [2] (p. 66) stated a paradigm: "how creative liberties can affect people's historical viewpoints and events." After a rapid analysis of the Hellenistic world under and after Alexander the Great, from the point that the Greco-Macedonian and the later Roman settlements could not have occurred 
without the Pan-Hellenic campaign against Persia by Alexander the Great, we can glean the following takeaways:

Hellenic (Classical) culture was adopted and adapted by the Macedonians and became a crucial element in Hellenistic civilisation; the latter was adopted and adapted by the Romans. The Macedonian king Alexander the Great's conquests (334-323 BCE) furnished the conditions to successfully restructure the ancient Greek Classical world of the fifth century BCE. Alexander's conquest of Asia Minor added to his empire and effectively spread Greek culture across vast parts of the known world [3] (p. 325). Essentially, he influenced Eastern and Western culture, which connected in a standard frame of reference for the first time, leading to proto globalisation. Despite being a Macedonian who was sophisticated with Greek values, his conquest found the Hellenistic kingdom set off a series of migrations and political realignments that broke open the relatively sealed world of the Classical polis [4]. However, Aristotle, who educated Alexander as a young man, influenced Alexander, and this marked his campaign planning and the methods and arguments of the importance of Greeks in relation to others, and even concepts of cultural diversity and intelligence: "Alexander is many things. He is logic, and he is dreams. He is warrior, and he is poet. He is man, and he is spirit. He is your son, but he's also *hers*... and he believes himself to be a god" [5].

Although Aristotle thought that an ideal government consisted of citizens whose ethics and education are adequate, Alexander took city and hinterland, town, and country together as a unit, not as spatially and socially distinct entities. Moreover, he had a deeprooted character beyond his military conquests; this included his interest "in learning and a technical side that allowed him to create strategies against imposing enemy numbers" (Fernandez, 2020, iii) [2] (p. iii). Finally, the influence of his achievements during his short life "cemented his legacy to this day" and can be detected in his verse talking to his troops before the start of the Battle of Gaugamela: "Conquer your fear, and I promise you, you will conquer death" [2] (p. 5).

When he invaded Egypt, he was welcomed by the Egyptians as a liberator and accepted as King of Egypt without a battle. Even he showed immense respect to the local people and their native gods as Amun. The most prominent image of him in the modernday Middle East region may be his inclusion in the Muslim holy book, the Qur'an [6] (p. 271), [7] (p. 34), which describes him as a "Pious world emperor whom God empowered with the lordship over all earth and constantly gave him success until he reached the place where the sunset and the place where the sun rose" [7] (p. 34). By the emergence of the Hellenistic age, after the death of Alexander, the barrier between Greek and "barbarians" as civilised and uncivilised was removed [8]. However, This Greek-barbarian dichotomy of the Classical age, we can assume, came to a head to excuse the concept of Europe and the Orient as opposites, particularly in the context of European imperialism [2] (p. 45, 58).

After the death of Alexander, the former Persian Empire was divided into several states, which are traditionally called kingdoms since their rulers chose the title "king" (Basileus in Greek) [9] (p. 103). Additionally, the Middle East region became a battlefield where his Diadochoi, the Seleucids and Ptolemies, fought for supremacy. Thus, during the worried decades following Alexander's death, Eastern Mediterranean cities developed strategies "to negotiate with the generals who became kings and monopolised military power but not ideological power" [9] (p. 106). Seleucids conquered Mesopotamia in 312 BCE and fought against Antigone in the Ipsos battle in 304 BCE, and they managed to win the battle. Thus, those two Greco-Macedonian kingdoms, the Seleucid and the Ptolemaic kingdoms, established in a vast non-Greek territory, underwent a parallel historical development. Antiochus in Syria and Pergamum in Asia Minor were other well-known centres of Hellenism in the Hellenistic world. 
On the other hand, a characteristic feature of the Hellenistic civilisation history was rapid economic development, finance, and organised trade growth. The ever-increasing mobility or connectedness was maintained throughout the Hellenistic period [10] (p. 36). According to Pitts and Versluys [11] (p. 163), over the whole Oikoumene, the Hellenistic institutionalisation system resulted in "an unparalleled circulation of goods and peoples and common practices. Along with that came the stress on local identities that is characteristic of a globalised world." The Hellenistic economies and polities, however, represented a new stage in global history. This allowed for the development of "new trade routes and just as important it increased cultural exchange" [1] (p. 5).

One of the consequences of Hellenistic expansion was the spread of the Greek language. However, the dissemination of Hellenism throughout the Middle East and Central Asia was "resulting in an amalgamation of Greek thought with local traditions and cus-

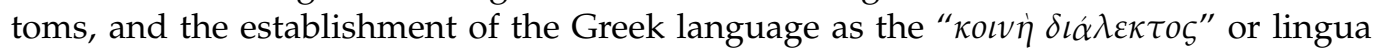
franca" [12] (p. 25). Pitts and Versluys [11] (p. 159), describing the system of Hellenistic koine, said, "it could be called the software of Roman visual material culture, came into being through a process of much-increased connectivity that spanned the whole known world, and that it functioned remarkably similar to our present-day globalising culture in terms of universalisation and particularisation."

This makes up the picture translated by an "Oikoumene world" to bond East and West into a progressive commonwealth. These brought on the process of so-called Hellenisation. However, Hellenisation of the ancient world essentially started long before Hellenism proper: "it began in the West with the dispersion of Greek colonies all over the Mediterranean, from northern Spain to Naucratis in Egypt, and in the East by very intense ties with the Persian Empire" [13] (p. 127). According to Coleman, [14] (p. 19) the origins of the concept of Hellenisation "may be traced to European historical analysis during the high point of modern European imperialism - a period when the imperialist powers rationalised their aggression and conquest as a civilising and Christianising process." Gruen [15] (pp. 264-265) labelled Hellenism as "the language, literature and learning of the Hellenic world' which under the rule of the Hellenistic kingdoms became the culture of the ruling class in the major cities."

However, on the other hand, Coleman [14] (p. 254) suggests that "the use of postcolonial theory has heuristic value in throwing up challenging new possible research questions and shaping new directions in research, both historical and archaeological."

Hellenisation also meant for many the diffusion of civilisational universalist concepts of socio-cultural, democratic, economic, scientific, and philosophic achievements and enlightenment, since adopting the Greek way of life did not mean abandoning native tradition. Rather, it was a way "for some non-Greeks (and especially for the local elite) to fulfil their ambitions, strengthen their social and economic position and achieve privileges" [16] (p. 228). Stavrou [16] (p. 228) said, "We cannot argue that the situation was the same among the lower social classes (Greek and non-Greek).

Assmann [13] (p. 127) framed Hellenisation with two faces. One refers to "the diffusion of the Greek language, ideas and customs all over the Ancient World"; the other face appears to be more of "a construction of a 'common culture', suggesting a similar change in Greece as in the other cultures." The Hellenistic world as a "multi-national" synthesis, however, considers other national cultures in the inputs. However, Assmann's [13] (p. 127) recognition of Hellenization is vital. For him, Hellenization meant, above all, "the diffusion of civilisational achievements such as the gymnasion, educational programmes and democratic institutions, and universalist concepts such as science, mathematics, logic, metaphysics and enlightenment." 
Meanwhile, the most impressive thing created by Hellenisation was the socio-cultural achievement after Alexander's death, but this cannot be generalised to the mass local agencies and their different perspectives about globalisation and interrelations, as it will be presented and discussed in the following sections. It was a failure; there was no absolute political unity, but a certain amount of cultural unity that kept the Hellenistic world together [17] (p. 18), [18] (p. 58) and [19]. The processes and products of this interaction prove that the ancient architectural interactions did indeed shape Western architecture [20] (p. 3). By conquering Alexander the Great's cultural perception of the Hellenistic age, disparate cultural traditions interacted to fix the permanent contours of European civilisation. Meanwhile, culturally its success rivals that of the Italian Renaissance, which was a rebirth of the Hellenistic world in which art and architecture were performative spaces that played a significant role.

This research focuses on the Hellenistic Middle East, especially the age of Ptolemaic Alexandrian and Seleucid influence. It examines the cultural interaction between these Hellenistic states and their neighbours and their socio-cultural influences. Focus is given to the transnational socio-cultural and economic aspects of Ptolemaic Alexandria and Syrian Seleucids, the centres of the post-Classical Greek world, where the transfer of goods, culture, and ideas transformed Middle Eastern cities and shaped their translocal cultural conception, local socio-cultural identities, cultural sharing, architecture edifice forms, and spatial patterns in the Hellenistic period.

\section{Assessment of the Hellenistic Oikoumene Age Culture and Globalisation Concept}

The notion of globalisation is not a new phenomenon. Its history can be drawn clearly, at least from the Hellenistic age. Hellenistic expansion represented the pragmatic proto globalisation of the ancient world. It is related to the Oikoumene of knowledge and the rise of the cosmopolitan, when commercialised urban centres of Greco-Macedonian culture like Athens, Pella, and Corinth in Greece, and Alexandria, Antioch, and Petra enhanced widespread trade and commercial links. This combination of political association and intellectual universalism is the hallmark of what Eric Voegelin called "the Ecumenic Age" [13] (p. 127), or the Oikoumenic Age.

Pitts and Versluys [11] (p. 62) characterised the whole Oikoumene, from 200 BCE onwards, as "one hyper network, which we should call 'global' to indicate the degree of connectivity and better time-space compression." They [11] (p. 164) confirmed that Hellenistic culture from around 200 BCE onwards was in itself already global, and was brought to dramatic time-space compression through the Roman conquest of "oikumene and its institutionalisation." However, as a research topic, globalisation has not prompted discourse on the meaning of "Hellenistic globalisation", including developing an emerging body of critical thought concerning globalisation relevant to Hellenistic urban and architecture practice. The principal reasons are to be found in the expansion of industry and commerce, enlargement of governmental functions, and the desire of former independent farmers to escape the hardships of serfdom. Now, the idea of world brotherhood was propagated by Stoicism's philosophy. This Classical notion of Greek-barbarian divide was criticised by Eratosthenes, the well-known geographer of Alexandria, and can be seen in his comment, "it would be better to divide the human race by the criterion of virtue and wickedness than into Greek and barbarians; for many Greeks are bad and many barbarians civilised" [2] (p. 45, 59).

It is here that one can find the paradigm roots of globalisation. Malcolm Waters [18] (p. 9) confirms his belief through his brilliant guiding theorem for the globalisation process: "material exchanges localise, political exchanges internationalise, and symbolic changes globalise." Meanwhile, Ward [21] (p. 7) believes that "few archaeologists would like to admit it to themselves, the focus on the 'Classical', Greco-Roman remains of the Near East privileges imperialism over the indigenous peoples of the Near East." According to Assmann [13] (p. 133), in antiquity, "the imperialism and internationalism of globalisation find its most explicit expression in the Graeco-Egyptian Isis religion." More analytically, in 
antiquity, imperialism "never implied assimilation; that is, the imposition of the laws and manners of the dominant civilisation onto the subjugated societies" [13] (p. 127).

Also of significance is understanding the concept of 19th-century European imperialism and colonisation of the rest of the world. We have to realise the vision of human history at that time, which was provided with the rationale to see themselves "bearing the 'white man's burden' of bringing civilisation to the benighted savage races of the world" Coleman [14] (p. 10). Strootman [22] (p. 29) concluded that "The postcolonial paradigm of the 1980s and 1990s, which relied heavily on Edward Said, did result in a more positive evaluation of the eastern aspects of the Macedonian empire in Asia in modern scholarship and a better understanding of Orientalist stereotype in both ancient and present-day historiography. It is questionable, however, if it has really created interest in the so-called eastern side of Alexander's and Seleukos' empires, and whether it really constitutes a new approach".

Edward Said (1978) states that "Orientalism and Hellenism are radically incomparable." He defines Orientalism as a discourse exterior to the Orient, refusing selfrepresentations of peoples constructed as Oriental [23]. According to Ward [21] (p. 1), Edward Said's Orientalism (1978) argues that "the image of the Middle East (Orientalism) that was created by 'western' (mainly French) writers and artists in the 19th century justified European imperialism in the region." This supported imperialist activity in the Middle East and similar justifications can be detected in modern authors, such as Huntington's Clash of Civilizations.

We can assume that the aspects of the traditional view can be problematic and are shaped, at least somewhat, by the theories surrounding the European colonising practices of the 19th century. Strootman [22] (p. 21) clarified that traditional scholarship has ignored non-Greek sources and "modern historiography does not know what to do with these Macedonian kings whose power rested on the support of Greek and Hellenized urban elites" and the loyalty of the non-Greek local elites. He concluded that "the reason may simply be that historians are still at a loss when it comes to choosing whether the Seleucid kingdom was a 'western' or an 'eastern' empire. The debate has developed into a virtual deadlock because some have insisted that it was either a western or an eastern empire" [22] (p. 21). Assmann [13] (p. 128) assumes that assimilation was "never a political issue but only a cultural option." Gills [24] (p. 60) argues that "in fact what we are witnessing is a 'historical reversal' of capitalism and a worrying 'crisis of democracy'. Globalisation is producing what I can call the 'New Hellenism'." He clarified that "in keeping with the belief that a historical perspective can be instructive, the experience of Hellenism is offered as an interesting analogy" [24] (p. 61). However, Coleman [14] (p. 252) clarified that "modern postcolonial studies see change effected through the active agency of members of the subaltern culture as they seek to preserve their shared symbolic values in a changing and sometimes hostile context. In this view, change is effected through the resistant strategies adopted by the colonised."

However, this does not mean that the concept of Hellenization is no longer viable for use in such a theoretical study. Instead, the concept is beneficial for understanding and defining the changes under the Macedonian kingdom, particularly when searching for signs of extensive Greco-Macedonian presence and contact. We must accept that Hellenisation's cultural impact is not simply one-way, from Macedonia to its provinces, in an attempt to Hellenise the province entirely, but a process in which each impacted area was affected uniquely. It is well known that the native civilisations of the eastern part of the Mediterranean had their unique cultural characteristics and came into connection with many other civilisations as early as the Late Bronze Age and Early Iron Age, including Greek civilisation, mainly through their commercial activities. Hellenisation, then, is a dynamic and much-discussed subject. Hellenisation can best be labelled as the process in which Greco-Macedonian influence was exerted onto a particular place and how that place adapted to and utilised the influence. 
These issues are particularly prominent in the study of Hellenism, mainly because the Hellenistic world has been seen as an area where Greek culture continued to thrive and where the Eastern impact was minimal and gradual. This idea is by no means just a modern one-the West considered Classical Athens to be the centre of Hellenic culture because of its cultural value as the home of philosophy, rhetoric, drama, and other such arts; architecture; and its reputation for piety. The issue, however, is the implication that Middle Eastern Hellenism could not have been affected by the Greco-Macedonian word or was minimally affected because it was a political and cultural centre. This view is fundamentally misleading for several reasons, but the most notable flaw is the hypothesis that many Hellenistic Eastern cities would not have been affected by such interactions. This viewpoint is undoubtedly changing, but the traditional ideas still hold some weight in how scholars view the Classical Age of Athens, particularly in areas where the city was believed to have excelled at its height.

To conclude, although the Greco-Macedonian lifestyle did not equally influence the non-elite strata of the indigenous inhabitants and despite the condemnation of the institution by parts of the native inhabitants, the Greco-Macedonian lifestyle in the East continued to be adopted in the Roman period and adapted to the policies of Roman rule. Thus, its legacy of cultural features was combined further with local traditions and practices.

The Hellenistic world cannot be considered an actual "capitalistic society" with significant gaps between the rich and the poor. However, Bintliff [25] (p. 288) states that the "imperial mosaic of prosperity and key export regions is increasingly characterised as a proto-capitalist economy." This is because the economy of the Hellenistic period combined with some new technological inventions immensely impacted the growth of Near Eastern cities, where social and economic changes had already occurred during the Classical period. Nothing marks the intensification of interregional movement of goods better than the chart of (essentially) West and Central Mediterranean shipwrecks, where a logarithmic rise and fall can be dated at least from the second century BCE to the end of the second century ACE [26]. Furthermore, Marvin Morris [27] (p. 1) presents the Hellenistic world as "a web of complex interconnectivity where architectural, technological, and artistic expression was exchanged from one corner of Alexander the Great's vast empire to the other." Indeed, the natural and authentic scientific investigation and revolution happened in the Hellenistic age, in which the Antikythera mechanism, described as the first analogue computer, is just an example of this revolution. According to the historian Farrington [28] (p. 301), Hellenistic science stood on the threshold of the modern world. When modern science began in the 16th century, the Hellenistic world let off [2] (p. 47).

However, we should remember that although the Hellenistic period saw the weakening of status boundaries in the Greek polis, land ownership remained the privilege of citizens only [29]. There is a growing recognition that the tendency in the Hellenistic world was to allow the regional societies to be run by wealthy landowners, merchants, and other entrepreneurs [30]. However, Hellenistic cities offered splendour and luxury for the wealthy, as centres of trade, science, and arts, while large portions of the population lived in miserable conditions. The distribution of large estates marks market production by more prominent landowners and other wealthy sectors for the elite population as the Macedonian kingdom expanded its territory [31].

\section{Investigation of the Hellenistic Localist Mode of Expression and Translocal Culture Conception}

Strootman [32] highlighted how the Ptolemies and the Seleucids adopted and adapted Near Eastern ideologies of universal empire, just like Alexander before them. The earlier examples of interaction between the Ptolemaic kings and the local elites down to the mid-third century BCE were usually expressed in a localist mode of expression. The local populations incorporated the changing reality into their mode of expression and interpreted it from their local perspective. This mode continued while other possibilities opened from the mid-third century [9] (p. 106). This is also reflected in the poems of Meleagros, whose 
father was a Syrian Greek and his mother in all likelihood a native. He writes, "If I am a Syrian, what the wonder? My friend, we inhabit a single homeland, the world" [2] (p. 45).

As Strootman [33] clarified, "translocal culture" means a culture that "stresses-and tries to facilitate- the connection between at least two places and the traditions and cultural memories attached to each." According to Dorothea Stavrou [16] (p. 221), they had to deal with both the multi-ethnic population having distinctive cultures, traditions, and practices of non-Greeks (natives or not) that inhabited these areas and with the Greco-Macedonian settlers and soldiers who came to the newly established kingdoms to support royal power and the Greek way of life. However, the degree of integration/assimilation and mutual influences was not the same in every part of the Hellenistic world. The Hellenistic "kings ... did not aim at ethnic supremacy but simply at political supremacy [in order] to reach their socio-economic goals" [10] (p. 8). Therefore, even the farmers outside the town were integrally part of the polis [34] (p. 43). Tesse [10] (p. 43) believed that the development of what can be called the Hellenistic farm phenomenon, in light of the vast increase in field survey data available today, should be understood as a Mediterranean-wide development rather than as a consequence of Roman colonisation [35]).

The diversity of the Pan-Mediterranean Hellenistic world, the golden age of wealth and democratic state, is evident, whereas the Oikoumene did not hold together under a single head. Ptolemies, Antigonids, Seleucids, and others warred with one another ceaselessly. These Macedonian successor kingdom rulers imported Greco-Macedonian colonists "who either founded new cities (often named after their Macedonian rulers or cities from the Greek mainland) or completely transformed existing settlements" [36] (p. 4). However, it is worth mentioning that the first cities founded by Philip II and Alexander were in European Thrace [37]. This phenomenon was sustained by Alexander, who has at least 20 cities named after him. Seleucus I also continued founded several cities (Seleucia on the Tigris, Seleucia on the Hedyphon, Seleucia on the Eulaeus, Seleucia on the Erythraean Sea, and Apamea on the Selea, among several others). There were undoubtedly some very significant developments in terms of the number of cities and their geographical extent.

Overall, in the Hellenistic period, well over one hundred new cities were founded in Asia Minor, Syria, Palestine, and Mesopotamia, and to a lesser extent, further east and south [38]. For example, the Seleucids left a developed infrastructure (they created defensible roads by constructing fortresses and fortified cities). Moreover, they assisted in building up the Silk Road by connecting Central Asia more closely with the Mediterranean, showing that their relatively more significant interest in the West than that of the Achaemenids could benefit the East. Furthermore, "for what it is worth: they enriched Middle East warfare for centuries to come with the heavily armoured war elephant and the cataphract, the mailed cavalryman riding a heavy warhorse of the type that was bred on the Nisaean Plain of Media" [22].

Meanwhile, the Greco-Macedonians were primarily bearers of Greek art and culture of ancient Greece. It was at the height of its power by the Hellenistic period; their own visual culture was enriched due to Alexander's conquests [39] (p. 369). Alexander and what his successors made of him placed him at the heart of the impact of Macedon on the art of Central Asia [39] (p. 380). Not only that, but the art and the architecture was also used to demarcate and integrate the planning of the urban built environment with concepts of local cultural sharing. Seignobos [40] (p. 33) determined that the unity of civilisation was the work of Greco-Macedonians, whereas the unity of government and state was the work of Romans. A Roman tradition derived from Greek culture shows that the Romans took over Greek traditions as much as the local cities took over Roman culture [41] (p. 37).

\section{Investigation of the Material Culture, Historical and Archaeological, and Expression of Local Socio-Cultural Identities: Hellenistic Oikoumene and Globalisation}

This section explores the theoretical context to study whether and how specific Hellenistic societies reacted to globalisation tendencies in the past by reviewing critical literature on globalisation and cultural identity and discourse. In addition, it pays close attention 
to the ways this literature relates to the urban built environment under contemporary globalisation processes.

Over the past few decades, the appearance and continued significance of local, civic, and ethnic identities under growing Hellenistic influence have attracted particular scholarly interest. Consequently, identity has in recent years been a constant topic of discussion. In contrast, cultural identity is an active and much-discussed topic: "the common educational features that existed in the Greco-Macedonian education and the native educational practices, in combination with the high level of literacy they fostered, could serve as a cultural bridge between the Greeks and the members of the non-Greek local elites" [16] (p. 230). It is of significance to emphasise that the "ethnically coloured identities seem to increase over the period of growing tensions with Rome and other powers in the Hellenistic age" [10] (p. 36).

The fundamental question, for archaeologists, is how identities are reflected in the material culture, the historical and archaeological, or how the material world and societies interact. Of importance, Albert Naccache [42] (p. 29) argues that despite all extraordinary evidence that archaeology has revealed in the past few decades, "it is never the aim of the histories of Syria and the Near-East to relate to the actual inhabitants of the area the history of their ancestors or to tell them where they come from, and thence who they are." However, Stavrou [16] (p. 226) explained that the Hellenistic kings did not try to integrate the native inhabitants but instead showed a "tolerant attitude and allowed the co-existence of the Greek and the non-Greek element."

In these places, the Greco-Macedonian element coexisted with the non-Greek population, thus creating an amalgamation of Greek and native cultures that were adopted and adapted. In this multicultural environment, the residents who probably belonged to the local elite of Syria and Phoenicia adopted the Greco-Macedonian world's way of life and introduced it to their communities. On the other side, Gruen also argues that "the Ptolemies did not require the imposition of Hellenic culture upon the inhabitants of Palestine" [15] (p. 265), [43]. Thus, in 175 BCE, the establishment of Greek educational institutions in Jerusalem and its transformation into a Greek-type polis met with little reaction from the Jews [16] (p. 221).

\subsection{Expression of the Lingua Franca and Local Identity in the Hellenistic Oikoumene}

It is essential to clarify that the investigation of linguistic practice at a specific place or within different elements of the inhabitants or a region is more likely to provide valuable insights than generalising affirmations of Greek as the lingua franca of the Eastern Mediterranean [14] (p. 27). The Hellenistic presence made Greek a common language. However, there was also "a myriad of older local traditions that turned this region into a mosaic of different zones with different histories" [14] (p. 162). In the Hellenistic world, we see the simultaneous use of two significant linguae franca, Aramaic and Greek, as a tangible sign of pro-globalisation [44] (p. 202). The Greek language during the Hellenistic period was becoming "a lingua franca of the elites in the oriental belt continuing from Indus to Mediterranean shore" [2] (p. 53). Assmann's clarification [13] (p. 129) of the concept and meaning of the lingua franca concerning local traditions is very comprehensive: "Greek was exactly this: a lingua franca; that is, a medium rather than a message" [45].

It offered a common language in which local traditions and religions could be expressed in a much more eloquent, flexible, and articulate voice than their own. For example, the "Ptolemy the recluse" archive from Saqqara-where Greeks and Egyptians (and others) lived alongside the temple precinct-provides rich evidence of this environment. In the south of the country, mainly in Pathryis, Egyptian legal scribes wrote many documents in Greek and acted as a "bridge" between linguistic communities [46] (p. 286). It certified local traditions to become internationally visible. It seems likely that the local languages were "the most spoken ones, remaining Greek been used as purely for administrative purposes" [36] (p. 157). 
On the other hand, all these codifications of cultural and historical traditions pursue the same dual goal: to release local traditions that were deemed endangered from oblivion, and to make them visible on the international stage of Greco-Oriental literature. According to Paffen [41] (p. 39), regarding the question of whether publics in the eastern provinces, where they primarily spoke Greek, understood the legends in coins written in Latin, "this argument has been countered by the fact that, even though the legend was not understood, the powerful symbolism of the image would have conveyed the message as well."

In Egypt, cultural interaction communication is expressed by several languages coexisting, but ultimately, "Greek and demotic bilingualism emerged" [46] (p. 286). The Archive of Tefhape hints at the relationship between "the Greek-writing bureaucracy and the Egyptian population" during the Ptolemaic period. This archive documents a family disagreement over land that finished in a trial at an Egyptian temple. The Ptolemaic officials were standing at the trial; before that, they responded to family petitions at the beginning of the disagreement [46] (p. 287). In another case, Egyptian priests were placed with Greek officials, apparently to act as interpreters of Egyptian law. Thus, according to Manning [46] (p. 286), bilingualism, irregularly documented among Greek officials, may have been more common than is usually thought.

More evidently, Manning [46] (p. 286) refers to Greco-Egyptian intermarriages among the many personal communication events across cultures. He clarified that "marriages between Greek soldiers and Egyptian women are incredibly well-documented. Whatever the language or circumstances, Ptolemaic rule created a bilingual linguistic environment" [46] (p. 286). Thus, all players created something new in the Greco-Macedonian and Eastern Pan-Mediterranean worlds in the vehicle of universal ideas and a grander lifestyle. Ward [21] (p. 6) concludes that we should see Syrians in the Greco-Roman world "as co-opting Greco-Roman culture to advance themselves within the Greco-Roman system." Consequently, it is essential to assume that the same took place in Ptolemaic Alexandria.

Andrade, examining the development of Syrian expressions of Greekness [21] (p. 6), ref. [47] and Syrian identity in the Greco-Roman world, argues that "Syrians, writing in Greek and engaging in debates about the nature of Greek culture, influenced the development of Greek identity in ways that have previously gone unnoticed. He sees Greek and Syrian cultural expressions as overlapping sets utilising polyvalent symbols (symbols with multiple meaning) which interacted in complex ways" [21] (p. 6). Thus, for example, Meleagros seems to have known some languages of the Orient spoken in the Hellenistic world. This is reflected in a poem where he says, "If you are a Syrian Salam. If you are a Phoenician, Naidius! If you are a Greek, Chaire and say the same yourself" [2] (p. 45). Regarding the emergence of local identities, Tesse [10] (p. 36) argues that it "cannot be seen apart from the Roman agency: on the contrary. This is, of course, and not coincidentally, in perfect harmony with current thought on modern globalisation and on understanding local developments within it."

To conclude, by studying the relationships between identity, culture, and artefacts, Butcher [48] argues that Roman Syria and the Near East individuals who chose to adopt Hellenic culture allowed them to obtain significant advantages (local autonomy and entrance into a unified elite that spanned the entire power empire) [21] (p. 6). Meanwhile, Sartre (2005) argues that Greek or Indigenous people of the Middle East under Roman cultures formed a third culture, a hybrid of the other two, and Greek became the lingua franca to express those identities [21] (p. 6). This lingua franca concept is like Babylonian, the lingua franca of the Late Bronze Age, as Aramaic was for the Persian Empire, as Greek was for the empires of Hellenism and Late Antiquity, and English is for today's internationalism. Such a lingua franca is the most significant implement of globalisation [13] (pp. 124-125): “We only may speak about a distinctive multi-ethnic group of people that adapted to, respected and lived according to the Greek way of [16] (p. 229). 


\subsection{How Was Local Identity Expressed on Coinage in the Hellenistic Oikoumene?}

A combination of aspects deemed of particular importance defined the identity of the Greco-Macedonian and Hellenistic world. The most critical aspects were religion, the past, and descent [41] (p. 57). However, no doubt the most convenient and documented local resources are coins [49] (p. 37); Millar has described coins as "the most deliberate of all symbols of public identity" [50] (p. 230). According to Paffen [41] (p. 37), coins in antiquity "not only served as a tool for the exchange of goods but also as a way of expressing one's identity." She discussed and clarified how we could learn about local identity and the relationship with Rome from these coins.

In the Hellenistic world, there was the spread of "a common, international standard of coinage with approximately the same weight standards from Gibraltar to Taxila and a shared system of iconography to guarantee monetary value" [44] (p. 202). A general overview of the development of Hellenistic coinage and Hellenistic coin production and design, as well as the Roman coinage itself of the late Republic (from the death of Julius Caesar in $44 \mathrm{BCE}$ ) and the early Principate (up until Galba), was greatly thematically influenced by Hellenistic culture [41] (p. 37).

As is known, the Seleucids left behind them an incompletely coin-based economy and a developed infrastructure (they created defensible roads by constructing fortresses and fortified cities) [22] (p. 34). For example, when the Parthian kings began to strike coins on which they appeared with tiaras and other Persian insignia of royalty in the late third century, this has been rendered a revival of Iranian culture [51]. These and other, notably Bactrian, coins show that only from the late third century were vassal kings established in various Seleucid cities in the east and began to strike coins [36] (p. 31). For example, coins minted by the local Persis kings show that the Pars Province had an internal autonomy ruled by local governors. According to AmiriNezhad [49] (p. 37), "no doubt, these coins contain some special political and religious symbols rooted in their past" [49] (p. 37). Plentiful coins originated from Hellenistic times, which were kept in production by the Romans but adapted to the Roman culture. Paffen [41] (p. 20) concluded that "This means that here we have the first sign of a Hellenistic tradition that is taken over by the Romans and turned into something of their own." Generally, we can summarise the main changes in the Hellenistic period for the matter of coin production as follows:

- The first to decide not to strike coins in his name was Alexander the Great. However, he continued minting coinage under the name of his father. According to Paffen [41] (p. 18), this practice of posthumous coinage became "very popular in Hellenistic coinage and later during Roman times. The purpose of this posthumous coinage was to indicate dynastic continuity, as well as that they would be familiar to the public and therefore widely accepted." Coins were now significantly standardised, as was the appearance of smaller denominations. This uniform currency was promoted by Alexander the Great.

- After Alexander's death, for 250 years, the iconography on Hellenistic coinage did not change significantly. All stuck to Alexander's model, taken over by almost every Hellenistic king [52] (pp. 10-17).

- The mints of the Greek cities in the Hellenistic period mainly produced coins with images often looking back on local cults. The coin's obverse usually bore the head of a deity [53] (p. 2).

- When the power of the Hellenistic kingdoms started to diminish in the second and first centuries BCA, the authority over coin minting appeared to fall into the hands of individual cities. This led some of these cities to produce local coinage immediately after the shift in power [53] (p. 23). Paffen [41] (p. 60) thinks that in the iconography of provinces' coins, "there are a couple of strong examples of Roman and Hellenistic culture combined and Roman themes derived from Hellenistic culture."

- In the Hellenistic period, there was already "a combination of local themes and universal themes on Greek cities' coins" [41] (p. 21). However, Greek coins took 
over in Roman times and demonstrated far more nominative cases than before [53] (pp. 13-14).

- The existence of a magistrate's name on a coin throughout the Hellenistic period meant vast pride and advertisement for his patriotism, particularly if he helped to pay for the production of the coin type [52] (p. 131).

- The Eastern Roman provinces already had a long history of symbolism on their coinage from Hellenistic times [54] (pp. 32-33). Moreover, Hellenistic culture directly and indirectly (via the Romans) inspired local coin production in the provinces [41] (p. 59).

- $\quad$ Roman provincial cities used themes they were already familiar with in Hellenistic times, especially in the eastern part of the Empire, and based their coin design on local religious themes and traditions [41] (p. 36). However, many Roman themes, "such as the cistophori, even themselves are inspired by Hellenistic tradition" [41] (p. 55). Most reverse designs remained local themes even in the "Romanised" coin designs [53] (pp. 24-25). Of significance is Paffen's assumption [41] (p. 60) that there was "not a straight division between two different identities on coins (imperial and civic), but that the identity of these cities was both civic and Roman."

- Coins define the Indo-Greek kingdoms' political and economic importance and point towards the cultural influences of the Indo-Greeks in South Asia. The bilingual and biscript coins used by the Indo-Greeks continued to influence Indian epigraphy until the Guptas. The Indo-Greek coins also integrated Indian and Greek deities to legitimise their rule and currency [55] (p. 374).

- Katsari [56] (p. 214) argues that the local authorities asking for permission to mint coins was not seen as something negative or undermining, but as a privilege, as well as the city likely having profited from the coin production.

Paffen [41] (p. 56) concludes that after the Roman occupation, coin production was mainly "allowed to continue as it was, but the emperor had absolute control. He did not use his overall power very much, but let cities mostly do their own thing, for example, use their denomination." Burnett and Ripolles [57] (p. 1) also consider that the Romans, in most cases, let local coin production continue as it was before the Roman occupation, which implies that the product could have remained varied in different cities [41] (p. 23). Finally, regarding "Roman Hellenism," Paffen concluded that "there is a strong sense of 'double belonging' in the case studies, and that Romans were inspired by Hellenism as well." To make this point more apparent, the image below (Figure 1) shows a basic model of how different traditions, and mainly the Hellenistic one, inspired the coin iconography of the Greek cities in the Roman Empire and how these different traditions inspired each other [41] (p. 59).

Therefore, we can make a relevant argument in the context of the Hellenistic Middle East that Hellenism's ideas, images, symbolism, and ideologies were reinterpreted as they intersected with local conditions and agencies. Similarly, Hellenistic Middle Eastern countries invented their local versions of the "Hellenism Model." These new versions were sometimes consistent and other times inconsistent with Western versions of Hellenism. Such a poly-nuclear Hellenistic model of communities, centred on a new, Eastern GrecoMacedonian power structure, presupposes somewhat different models of only cultural change and exchange, far removed from the traditional urban "radiation model," and suggests much more socio-economic and cross-cultural interaction and cooperation in the creation of these communities on the ground. 


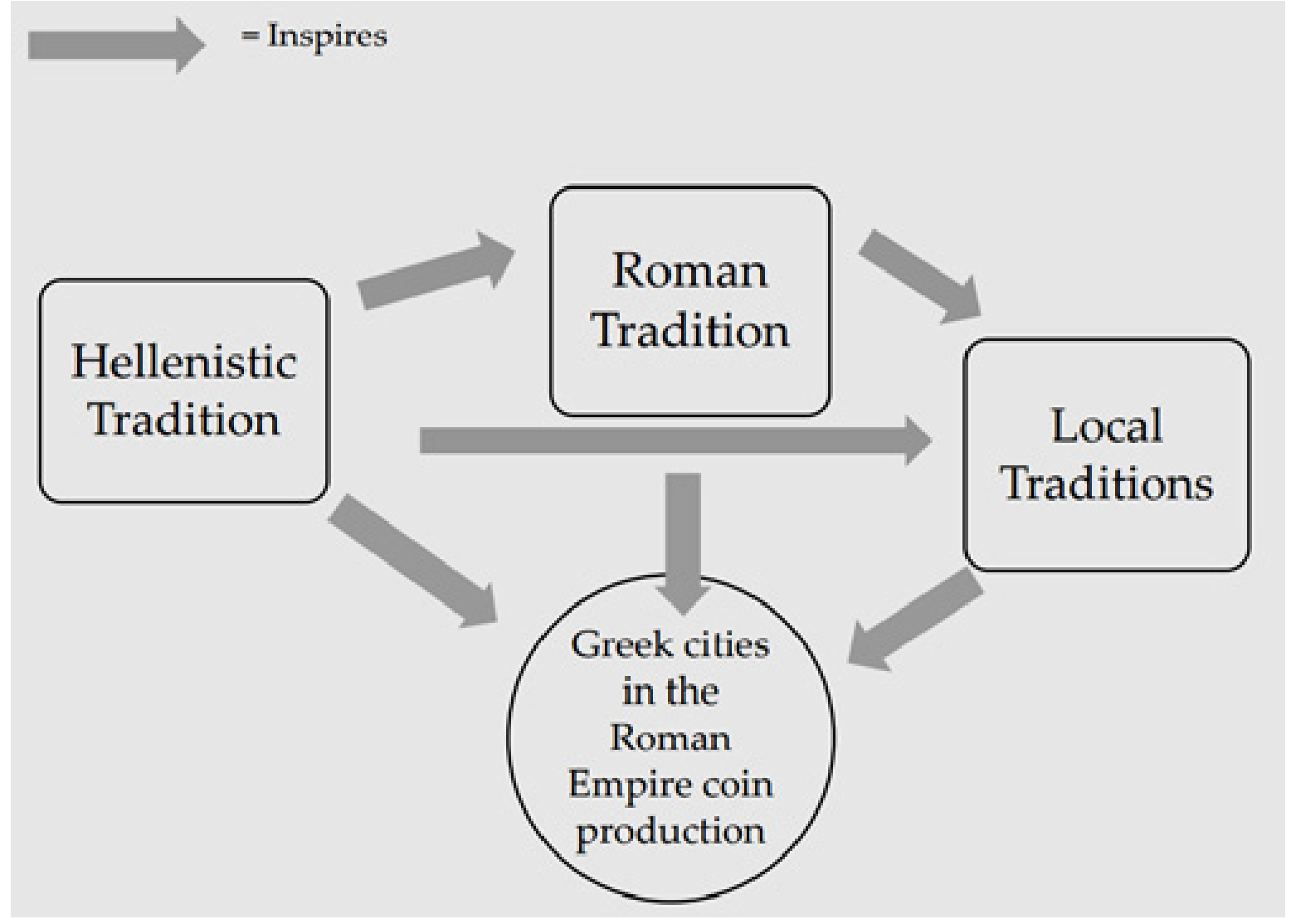

Figure 1. Model of the relation between different cultures and coin-theme inspiration (adapted from [41] (p. 59)).

To summarise, "a co-existence of diverse philosophies is not only possible but necessary" [58] (p. 518) and [59] (p. 22). However, Hellenistic globalisation resulted from a cross-cultural interaction synthesis between the courageous sensibleness of the GrecoMacedonian mind and the sensitive, creative Eastern mind's vision of preserving traditional elements and practice. The result was providing fruitful ground for the articulation of a worldview that transcended. However, the Hellenistic globalisation model that Alexander employed was quite different from the Roman one as well as most if not all of the models of globalisation ever since, including, to a certain degree, the model of the current one.

\section{Investigation of the Hellenistic Oikoumene Art, Architecture, and Urban Built Environment Planning: Cultural Sharing Achievements}

Art and architecture as a cultural symbol were as important in antiquity as in our time. However, when interpreting art, architecture, and urban built environment planning, we should consider that they reflect any society; this reflection helped define and perpetuate many of the social constructs inherent to society. This section offers a general evaluation of Hellenistic Oikoumene based on art, architecture, and urban built environment planning. They were vital components in consolidating Hellenistic power over settled lands. They indicate how they shaped lives and thoughts, especially of the creative people of the ancient Mediterranean. They became, in this case, a platform through which ideologies of the era were reflected. The Hellenistic model can be defined by analysing the buildings and urban forms in the Mediterranean region of the third and second centuries BCE.

We can find several cases where Western and local Hellenised architects referenced their designs to local culture or history or incorporated specific vocabulary in response to existing conditions, producing different architectural forms in different cities and even in the same city. Here, a key factor is that Hellenistic art, architecture, and urban built environment planning started to form an organised industry. In addition, the new cities 
and the increased prosperity of some older ones created a new and more extensive but less demanding market. The new elements might be representative public buildings such as theatres and gymnasia. They even founded new cities ex novo. On the other hand, Haddad [20] (p. 29) argues that the first systematic development and employment of the pedimented and entablature doorway can be considered "one of the most brilliant transformations and systematisation of different Hellenistic architectural industries solutions versatile architectural implications and emulation."

\subsection{Hellenistic Oikoumene Art and Architecture: Globalisation and Localisation Paradigms}

Despite interest and personal reference, few works have identified contemporary discourse concerning globalisation and "Hellenistic globalisation" in architecture and urban built environment within the larger body of globalisation literature. Regarding contemporary architecture, some of the samples are El-Sheshtawy and Abul Nagga [60], who discuss sustainable urban development in an age of globalisation. Lefaivre and Tzonis [61] discuss the issue of architecture and identity in a globalised world. Adam [62] discusses globalisation and architecture: The challenges of globalisation are relentlessly shaping architecture's relationship with society and culture. Meanwhile, Eldemery [63] analysed globalisation challenges in architecture, and Licka and Roeh [64] and Hewitt [65] discuss the relation between globalisation and landscape architecture. Meanwhile Mahgoub [58] presents globalisation and the built environment in Kuwait.

Since the end of the fifth century BCE, Macedonia was a locus of Greek [66] (p. 13). The Macedonian art era logically forms part of Hellenic artistic heritage, and there is no sharp boundary between Greek and Macedonian in the artistic sphere. Smith [67] (p. 7), in his work "Hellenistic Sculpture," states that he believes that this period was "a time of major innovation and picks out variety, subtlety and complexity." Meanwhile, Robertson [8] (p. 68) has argued that "much of what happened in art in the Hellenistic period is development inherent in art itself." The result was that one of the tendencies, if not one of Hellenistic art's main characteristics, was industrialisation [17] (p. 195). For the first time, museums and great libraries spread, such as in Alexandria and Pergamum. Indeed, the Hellenistic age was a time of sweeping innovation and experimentation in many areas. It was an epoch of excessive experimentation of the techniques and materials used in the production of mosaics. A pictorial stylistic school in mosaics can be witnessed by the beginning of the second half of the fourth century BCE, with Pliny describing this much later as "painting in stone" [68] (p. 173).

However, the outstanding achievements of the mid-fourth to early second century $\mathrm{BCE}$ reflected in architecture should not be seen as a new and unexpected phenomenon, but rather as a necessary development of pre-existing architectural traditions with new methodological artistic and symbolic skills (pictorial, theatrical, and metamorphic effects) $[19,20]$. From a morphological perspective, Hellenistic architecture from the beginning rejects the standardisation of orders, and references imitation to history and diversity and an exaggerated style of ornamentation. The façade treatments of Greco-Macedonian Hellenistic architecture can serve as a model for understanding the architectural aspects of ancient cultural interactions that open new visions to develop the aesthetic and stylistic architectural product. It offered further and excellent opportunities to capture symbolic architectural elements attached to a screen wall $[19,20]$. A crucial feature of the firm intention is that it was resilient rather than resistant while achieving a three-dimensional effect, thus producing compositions on a flat surface and creating the impression of depth thanks to the effects of what could be called "perspective drawing," which merged new features into the essential elements that form Greco-Macedonian and local culture and identity.

Through its concern for the exploration and stimulation of difference in aesthetic morphological experience, the Hellenistic conceptual approach might have artists, architects, and urban designers re-emphasise the production and consumption of symbolic capital as a significant part of the "Oikoumene system." For example, the wide application of a "new symbolic image" by utilising new forms of pediments and entablature associated 
with doorways (third to second century BCE) [19] (p. 201) is an excellent Hellenistic globalisation paradigm (Figure 2). The Macedonian and Alexandrian pedimented segmental doorways offer a telling image that produces a unique architectural model of the cultural interaction for Eastern Hellenistic architecture and art.

These pedimented and entablature doorways, as the earliest known Macedonian contribution to morphological Hellenistic architecture, demonstrate a crucial presentation and investigation of the development within their more oversized Pan-Mediterranean context of the Baroque style of Ptolemaic Alexandrian, Pompeian second style, Nabataean architecture, and later Renaissance [20] (pp. 26-27). Their excessive application is instructive as "the cultural Mediterranean accepted internationally form and practice by applying alternating triangular and segmental pediments" [6,19] and [20] (p. 28).

Furthermore, a localisation paradigm in the Eastern Mediterranean uses the crawstep as an excellent example of the active agency of the subaltern culture in sustaining an "indigenous symbol in a new context" [14] (p. 162). According to Coleman [14], the Levant's extensive use throughout the Hellenistic period of an artefact with deep cultural roots, such as in the Hellenistic temple at Jerash and most of the rock-cut façades of Nabataean Petra, is undoubtedly significant. As is known, craw-step/stepped-merlon crenelation is not Hellenic in origin, and it is an iconic Near Eastern decoration of antiquity and a signature architectural decoration of Mesopotamia that can be traced back to the third millennium BCE [69]. The composition of the western pedimented doorway, developed from the Greek post-and-lintel system traditions and combined with the Alexandrian Ptolemaic Hellenistic arcuated system of the segmented doorways, in addition to the craw-step of the iconic Near Eastern decoration, combine on one Nabataean architectural façade as the new Hellenism trend of facade expression.

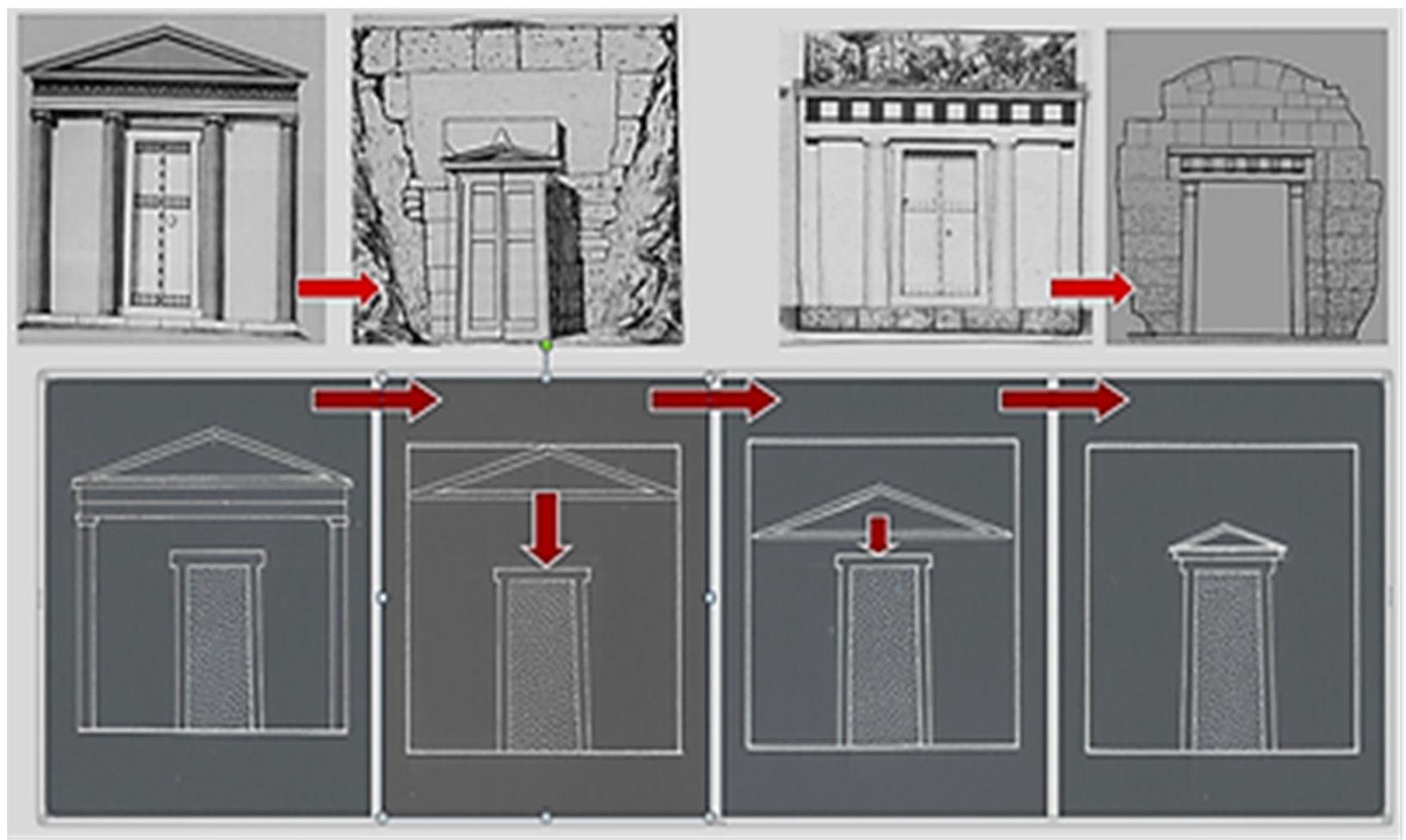

Figure 2. Representation of the new Hellenistic trend searching for symbolic artistic subtraction and interaction of the Classical prototypes in which the central doorway symbolised the whole structure. It is showing the process of the gradual lowering of the upper architectural elements (pediment in this case) towards the doorway to create the first application of the pedimented doorway. 
On the other hand, extensive production of Hellenistic theatres in the Eastern Mediterranean can be related to "personal cultural ambition" and the search for "corporate cultural identity" for corporate cultural communications. Recognised as a feature of Hellenistic Greco-Macedonian civilisation by the mid to fourth century BCE, the theatre continued throughout the first centuries $C E$ to represent the ideology and values of the economic forces primarily responsible for its production, including those of the Roman capitalists. Eventually, the theatre became a global "symbol of cultural sharing modernity," stimulating competition among cities to possess the most significant theatre building (Figure 3). Cultural sharing is the symbolic exchange between divergent groups, nations, and societies [18] (p. 12). Therefore, we can assume that the theatre case can be considered a "global-localisation," or glocal paradigm.

To conclude, local cultures seemed to want to convince the Greco-Macedonians by accepting and adopting the idea of globalisation by displaying these architectural elements, symbols, and structures. At the same time, their intention seemed to be a protection for local beliefs and thoughts. This was done carefully by creating a hybrid approach, taking into account the political dimension.

\subsection{Hellenistic Oikoumene Cities' Urban Planning, Globalisation, and Localisation Paradigms}

The cultural change in societies and its reflection on the products of architectural and city urban planning also changed architectural and urban planning practice through their represented images in architectural works and cities. Many Hellenistic and modern city paradigms support this theoretical approach of the co-existence model of the forces of globalisation and localisation in similar contexts, shaping the urban environment, as claimed by Satler [59] (p. 15), El-Sheshtawy and Abul Nagga [60], and Mahgoub [58]. These modern paradigms help understand contemporary globalisation and Hellenistic globalisation, joining the Oikoumene civilisation while responding to local conditions. These paradigms did not isolate themselves from that time of human development; they relatively efficiently and actively participated. They viewed it as another phase in human development that required positive and active participation from all parties.

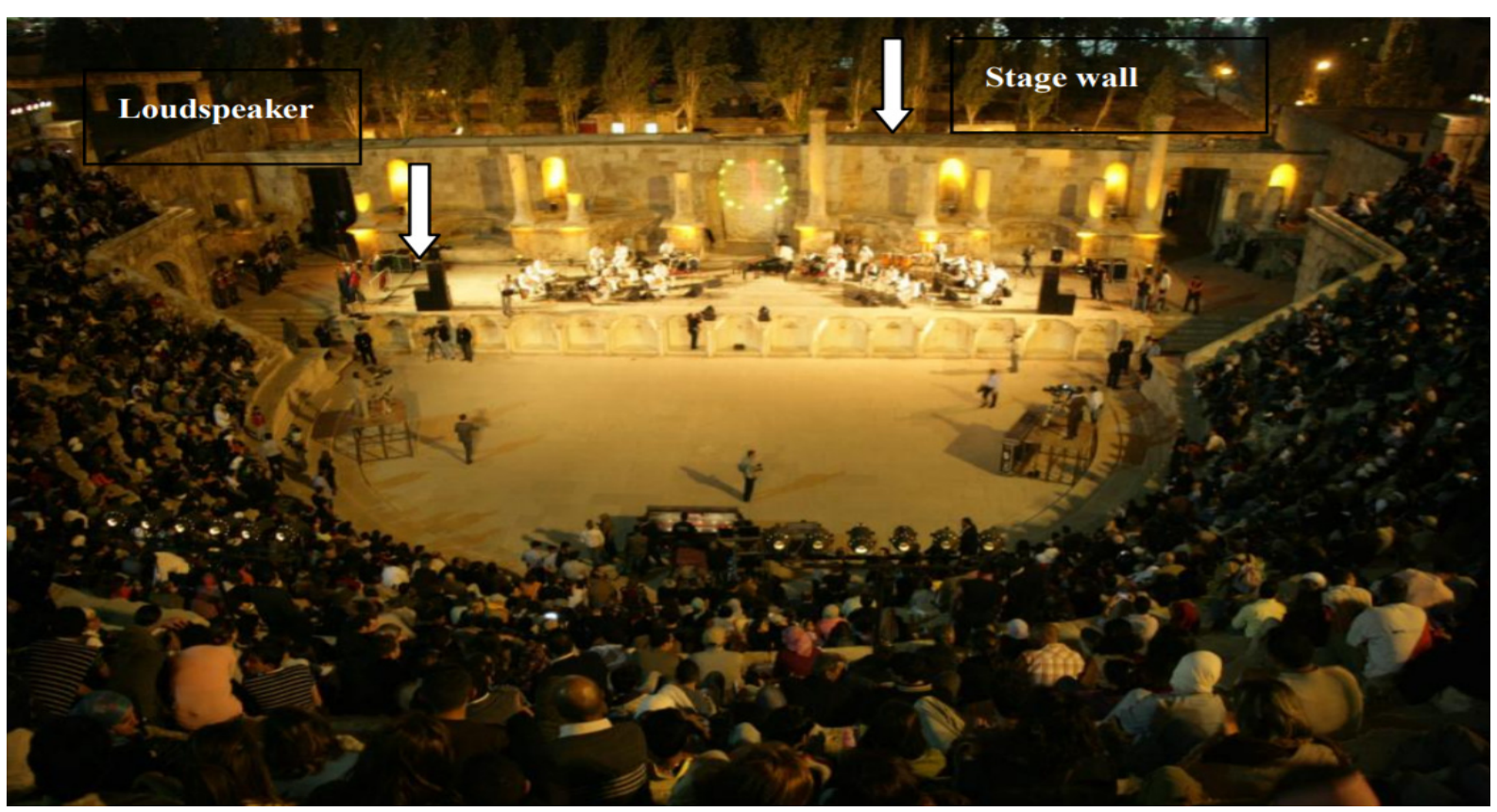

Figure 3. Amman Great Ancient Theatre reused for performances as a symbol of cultural sharing in modernity. 
Although population information is challenging to secure for the ancient world, it seems evident that the largest Hellenistic cities, including Alexandria, Seleucia on the Tigris, and Antioch on the Orontes, were of considerably more extensive scale than all but the largest of their Classical counterparts [4]: "For many scholars, the period from the death of Alexander in 323 BCE to about 300 CE was the height of Urbanism in the Near

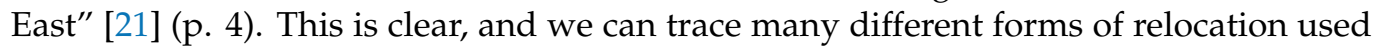
to achieve Oikoumene goals like synoecism/urban amalgamation and metoecism/urban relocation [70] (p. 193). Many different forms of relocation were practised to accomplish imperial goals, like synoecism or urban amalgamation and metoecism or urban relocation. For example, residents of cities like Hermia, Holmi, and Hyria were relocated to Seleuciaon-the-Calycadnus in Cilicia, an example of the process of synoecism [70] (p. 193).

An exciting result of the socio-cultural and economic conditions in the Oikoumene Hellenistic period was the growth of metropolitan cities. As in Alexandria and Petra, metropolitan cities consisted of a model of cross-cultural interaction, where these changes and their effects were experienced significantly. In Ptolemaic Alexandrian and Nabataean architecture, we can inspect this cross-cultural interaction by mains of adaptation and sharing $[6,19,20,71]$. Petra and Philadelphia offer examples of cross-cultural interaction and how Greeks were prepared to abdicate self-government to increase wealth and social standing. Nonetheless, Ward [21] (p. 6) summarised that "as Rowlandson notes, Philadelphia still possessed the two key Greek cultural institutions: the gymnasium and the theatre. Andrade [47], however, by examining Antioch, Apamea, and Jerash as examples of Near Eastern cities, argues that Greek and Syrian were categories that overlapped each other, both sharing and creating polyvalent meanings concerning each other. Therefore, we can assume that these cities' cases can be considered "global-localisation," or a glocal paradigm.

Finally, the Hellenistic Oikoumene practice regarding the city and its surrounding territory as one unit, that is, "the traditional unity of town and hinterland-political, juridical and residential-went on unchallenged" [72] (p. 307). The newly conquered cities overflowed with art and architecture that bore a solid Macedonian and Ptolemaic Alexandrian Hellenistic vocabulary. However, what was new about town planning was the care taken to integrate public buildings into critical parts of the grid where they would be convenient for access and make the best impression on citizens and visitors alike [4]. Real attention was paid to Hippodamian urban planning, where Priene, Ephesus, and Pergamum are samples of how the grid plan was reformed and moulded to house local topography.

\section{How Did Eastern Hellenistic Cities Manage to Benefit from the Process of Hellenistic} Globalisation and Localisation? Globalisation and Minimising Identity Risks

As has been shown, establishing cities and settlements was typical of Hellenistic rulers to form their dominance. The erection of new cities provided a cultural and economic impetus for the Hellenistic Empire to participate in the long-distance trade that emerged. However, these cultural and intellectual economic activities made the cities "a pole of attraction for teachers and foreigners who wished to participate in Greek paideia" [16] (p. 223). Underlying the Hellenised, and later Roman, veneer were limitless older local traditions and languages, which impacted Roman religious tradition by introducing new religious practices. A vital difference between the eastern and western provinces of the Roman Empire is that "sophisticated urban cultures had developed in Asia Minor and the Levant centuries before the Romans arrived" [36] (p. 153).

Considering this issue, we may conclude that, in contrast to the overall urbanisation process in the West, the previous Hellenistic socio-cultural substratum played a significant role in the everyday lifestyle reflected in city layout. However, the interactions with indigenous cultures of Hellenism affected the urban style of the old urban tradition, thus limiting themselves to overlaying distinctive features on pre-existing settlements or preexisting Eastern cities. Pre-existing cities were often refounded and given a new name, a name reminiscent of the royal family, a Macedonian city as in the case of Pella, or simply a Hellenised form of the local toponym [73] (p. 1). 
Even when Greco-Macedonian inhabitance settled those cities and introduced their representative features, they would not change the whole layout. This does not mean that "they had nothing to do in reorganising the urban space but, in several cases, they probably limited themselves to adapting what they found to the Hellenistic style") [36] (p. 158). Examples of how the Greco-Macedonians introduced their urban tradition to the Eastern one can be observed in the Decapolis cities in northern Jordan and southern Syria and Palestine, historically regarded as Greco city-states [74]. Evidence, however, of the strength of previous traditions lays in the fact that some Semitic names, such as Gadara or Gerasa, were preserved [36] (p. 157).

These cities were first; they all had an architectural history before coming under GrecoMacedonian and Roman occupation and were occupied by the Romans in a different way and time. This means that the relationship with Greco-Macedonia of these cities developed differently, making it noteworthy to study. Another reason is these cities all had different ways of dealing with their local identity in their architecture, how they balanced local and Oikoumene themes in the architecture, and that they all had enough available material to make a good paradigm. These could have influenced how the city developed and how it dealt with its local identity and architectural production. All these actions differ per city. Thus, it is interesting to compare the different situations and see this return in architecture.

Interesting enough is the study of Barghouti for this issue. Barghouti [75] elucidated cultural continuity when he cautioned against the architectural activity and town planning layout and arrangement in Palestine and Jordan as part of the same architectural and urban development in the rest of the Greco-Roman world. He rejected this position because it is biased and ignores traditional and native tendencies [75] (p. 209). While outwardly an Eastern city may look like it conforms to Western tenets of town planning, "its essence and nature are oriental" [75] (p. 211). One of the critical Eastern features that could work against the Western regularity of urban planning layout design was the approach and accessibility to temple locations. Whereas the Classical Greek approach could move a temple from the acropolis to the lower city, in the ancient Near East, " ... the numinous presence of the deity is so precisely located that the sanctuaries cling forever to the same spot" $^{\prime \prime}$ 14] (p. 237) and [75] (p. 237).

Many locations (especially in the rural areas) remained attached to local culture and tradition until a late period [16] (p. 153). However, the point that the region included great Greek poleis in Asia Minor facilitated the distribution of Greek cultural traditions and practices under the supervision and influence of the citizens and mainly of the elite. Contrary to what some historians have recommended in the past, the Seleucids did not neglect the East [22] (p. 28). On the contrary, they were always keen to accept local autonomy in return for tribute, military support, and formal acknowledgement of Seleucid imperial authority. Protecting civic autonomy "was the basis of their relationships with the Greek cities in the West from the beginning") [22] (p. 26). To conclude, each area under the Macedonian kingdom was unique.

\section{Ptolemaic Alexandria as a Paradigm}

Alexander the Great founded Alexandria in $331 \mathrm{BCE}$. Alexandria, an international port, had become the main centre of Hellenism. In $300 \mathrm{BCE}$, Alexandria was the central part of the broader phenomenon of Hellenisation that spread throughout the Eastern Mediterranean world during the centuries following the death of Alexander the Great in 323 BC [76] (p. 66). Just fifty years after its foundation and "at the beginning of the Christian era contained perhaps a million people-Egyptians, Persians, Greeks, Jews, Syrians and Arabs"; even an Indian population was living in Alexandria [2] (pp. 46, 48).

Alexandria city remains to explain how its art and architecture as the capital of the new Macedonian kingdom under the Ptolemies, the organisation of the city's spaces, the necropolis, and the shape of its buildings were inseparable from the formation of the Greco-Macedonian new nation-state. The new nation adopted a secular modernisation project, which replaced Classical Greece. This project was to be materialised through the 
spaces of the city. In other words, Alexandria's urban design and architecture were "the means" and "the product" of that project of modernisation.

It was a healthy city with healthy water and air surrounding a rich agricultural land, so Alexander described it as the most magnificent city ever built on earth, having the most wondrous buildings [77] (p. 61). As a significant centre of Hellenistic civilisation, it became one of the ancient Classical world's actual trades and economic capitals. As the centre of the post-Classical Greek world, Ptolemaic Alexandria played a crucial role in Mediterranean trade, controlled commerce between Egypt and the Eastern Mediterranean, and was a significant staging point for the northern Silk Road. By the end of the fourth century BCE, the core of the Hellenistic globalisation loom was conceived to create a new Macedonian national identity. Under the Ptolemies, even native Egyptians were trained for the first time in a specifically Macedonian manner.

As a cultural leader, it was the creative centre of new architectural and artistic forms that played a significant role in developing Western and Eastern architecture's formal and stylistic aspects. The legacy of the anti-Classical tendency was new in the architecture of the Ptolemaic age. The merging of the skills of both nations, Egyptian and Greek, was achieved in a sequence of likenesses that combined Egyptian materials and construction techniques with Hellenistic concepts and appearance $[13,20]$. This was the way Ptolemaic Alexandria was during Hellenistic times (a "meta-Athens"), where town and country in Ptolemaic Egypt saw the settlement of Greeks in mixed rural communities and the effect this had on native populations until, in the late Ptolemaic Chora, communities were effectively bi-cultural despite retaining Greek and Egyptian cultural distinctions [78].

On the other hand, there are different ways that Hellenisation affected and changed the Alexandrian landscape in the early Ptolemaic period, establishing a precedent for how the Greco-Macedonian and the non-Greeks would continue to interact with each other throughout the Ptolemaic period as well as how the local influence would be exerted and adapted into the Alexandrian burial religious sphere. As a characteristic example, Venit [79] (pp. 71-73) boldly emphasises that the monumental tombs of Alexandria provide the best evidence of the city's ancient character. There was no official city-state religion and no expectation that everyone participate in public forms of state-sponsored religion, worship, sacrifice, and festivities. Convincingly, Venit argues that the interest in Egyptian religion attested in these Alexandrian tombs cannot be relegated to indigenous Egyptians who had adopted Greek culture. The intermixing of so many groups, ethnicities, and various religious expressions is reflected in the organisation of these tombs. The Macedonians, especially the non-elite class, had far more choice and opportunity to try different religions to meet their needs from their home cities and traditions.

At no period in the city's history is there evidence of a particular necropolis for Alexandria's diverse ethnic groups; successive stages of redecoration and remodelling reveal that these tombs were the ending resting places of Alexandrian Greeks who had incorporated the religion of Egypt. Venit [79] (pp. 71-73, 79, 80-83, 91-95, 107, 124, $146,190)$ demonstrated the gradual infusion of Egyptian culture into all Alexandrian society levels, including the original Greek Macedonian elements of the city. This marked a refreshing departure from most of the comprehensive studies of Alexandria, which too often marginalise the Egyptian elements in Alexandria or relegate them to the lower classes [80]. However, comparing the painted architecture in Alexandrian frescoes, mosaics, and architectural elements with the early Macedonian tombs, it is conspicuous that many of the latter were found in Macedonia. We might assume that the shift from the Macedonian approach in facade treatments probably represents the shift in the Alexandrian cultural orientation from West to East, whereas in later cases, the architects tried to orientalise this Macedonian style.

According to Çinar [81] (p. 153), through "the making of the city" and its spaces, "modernism as a founding ideology came to constitute the social reality of [the city's] citizens." Through most of the end of the fourth century BCE, the city's architecture continued to incorporate features of the Macedonian architecture commensurate with prevailing 
Macedonian national identity, which was soon changed. The city and the funerary nature of both ensembles and the chronological correspondence confirm the hypothesis of an influence derived from Macedonian architecture upon the Egyptian necropolis, reflecting later upon Nabataean vocabulary. Nevertheless, Alexandrian architecture emerges in two similar and parallel evolutional ways [6]:

(a) The one that appears in Roman Italy, as expressed by the First Pompeian style of wall painting, moulded in stucco and coloured in imitation of masonry work, was popular in the town between 200-80 BCE, and there is earlier evidence for this style of pigmented stucco decoration from the fourth century BCE in Macedonia, Alexandria, Delos, and Carthage. The second century BCE was a period of growth and expansion in Pompeii, resulting from the town's development into an important port during the First and Second Punic Wars. Incredibly influential in this regard were the Second and Third Macedonian Wars (200-196 BCE and 172-167 BCE), the war with Antiochus III (192-189 BCE), and the conflict with the Achaean League (150-146 BCE). This treatment continued as expressed by the second Roman-style wall painting (80-20 BCE).

(b) The one we observe in Nabataean Petra, in the peculiar rocky nature of the region, where rock-cut sculptured architecture was a necessity; it is especially noticeable in the instance of the Anogeia facades sculpted in the rock, where free-standing architecture binds prototypes and becomes still laxer. As a result, the general appearance plays the role of sculpture rather than architectural work. Based on the notion of new architectural façade formation, starting with the Macedonian and later on shifting to the Alexandrian and Nabataean, the relation between form and function reformed architecture. This issue is evident, at least in terms of adopting the formal codeengaged order and pedimented and entablatured doorways $[6,19,20,82]$.

\section{Summary and Concluding Remarks}

The characteristic feature of the history of Hellenistic civilisation, the rapid economic development, finance, and organised trade growth, was combined with some new technological inventions, which had a stimulating effect that led to the immense growth in scale and socio-cultural development of Eastern cities. It may be further pointed out here that the modern idea and roots of globalisation have a strong historical connection to Hellenisation. Due to these socio-cultural, economic, scientific, and technological changes, the Hellenistic age was a time of sweeping innovation and creative experimentation in many areas and fields. These are reflected in industry and commerce, the enlargement of governmental functions, and the wish of earlier independent farmers to escape the hardships of serfdom and the everyday life of the natural and "authentic scientific investigation and revolution" of the Hellenistic age.

As a result, Hellenistic economies and polities represented a new stage in global history. However, the degree of integration/assimilation and mutual influences were not the same in every part of the Hellenistic world. Meanwhile, the Hellenistic Ptolemaic and Seleucid empire kings and rulers adapted to local traditions; the pattern of loyal patronage and the operation of local religious cults perhaps enhanced integration [33]. They did not try to integrate the native inhabitants but instead showed a "tolerant attitude and allowed the Greek and non-Greek elements to coexist." They did not even require the imposition of Hellenic culture upon the local inhabitants, thus creating an amalgamation of Greek and native cultures that were adopted and adapted in a somehow fair-minded approach.

Meanwhile, the Greco-Macedonian presence made Greek a common language; in the Hellenistic world, we notice the simultaneous use of the two significant linguae franca-a medium rather than a message-of Aramaic and Greek. However, usually, local languages were the spoken ones. The remaining Greek was used for administrative purposes, thus creating a tangible sign of a "pro-local globalisation mosaic" of different zones with different taste histories in which local traditions became internationally noticeable. To summarise, all players produced something novel for the Greco-Macedonian and Eastern 
Pan-Mediterranean universal ideas and a grander lifestyle, somehow of a hybrid resilience approach providing distinguished multicultural elements that attracted and respected different cultural identities.

More analytically, regarding the Syrian identity in the Greco-Macedonian-Roman world, Andrade [47], examining the development of Syrian expressions of Greekness, argues that "Syrians, writing in Greek and engaging in debates about the nature of Greek culture, influenced the development of Greek identity in ways that have previously gone unnoticed." In the meantime, during the Ptolemaic period, the priest class continued to keep their elevated position, with the native Egyptian religion even flourishing in Egypt, and cultural interaction communication expressed by coexisting with quite a few languages. However, ultimately, "Greek and demotic bilingualism emerged," where Egyptian priests were placed side by side with Greek officials, apparently to act as interpreters of Egyptian law. Thus, bilingualism irregularly documented among Greek officials may have been more common than is usually thought, as Manning argues [46] (pp. 286-287). In the case of Hellenistic coinage, after Alexander's death, for 250 years, the iconography did not change significantly. All stuck to Alexander's model. Meanwhile, the mints of the Greek cities in the Hellenistic period mainly produced coins with images often looking back on local cults. Thus, there was an amalgamation of local themes and universal themes on Greek cities' coins.

On the other hand, when Hellenism's ideas, images, symbolism, and ideologies were reinterpreted as they intersected with local conditions and agencies, it can reveal the neglected role of the non-Greek culture's contribution to Greek culture's achievements. The diversity of the Pan-Mediterranean Hellenistic Oikoumene world, the golden age of wealth and democratic state, is evident. There were undoubtedly significant developments in the number of cities, urban built environment planning, cultural interactive sharing issues, and geographical extent. Overall, over one hundred new cities were founded in Asia Minor, Syria, Palestine, and Mesopotamia in the Hellenistic period. In the three-hundred-year period of the Hellenistic period, one can see more architectural, artistic, and urban planning cultural sharing achievements than in any other three-hundred-year period in the ancient history of architecture. However, the primary argument lies in the following development: The influence of early Macedonian architecture can be detected in many of Egypt's early to late Ptolemaic and early Roman architecture, as can be detected in many Pompeian and Nabataean buildings, apart from the funerary context.

The Hellenistic Oikoumene globalisation image and simulacrum, we can say, is a co-existing model of the forces of globalisation and localisation, in which the Hellenistic economies and polities represented a new stage in socio-cultural global history. In this context, the wide application of a "new symbolic image," for example, by utilising new forms of pediments and entablature associated with the doorway (third to second century $\mathrm{BCE}$ ), is an excellent Hellenistic Oikoumene globalisation paradigm. On the other hand, a localisation paradigm in the Eastern Mediterranean uses the craw-step as an excellent example of the active agency of the subaltern culture in sustaining an "indigenous symbol" in a new context. Moreover, the Hellenistic world represented a quick expansion and integration of the East with the West with a shared cultural frame of reference, which should be an excellent paradigm of the "glocal" to rethink the present East-West dichotomy. In this context, we might consider that the production of Hellenistic theatre in the Eastern Mediterranean can be related to "personal cultural ambition" and the search for "corporate cultural identity" for corporate cultural sharing communications. Therefore, we can assume that the theatre case can be considered global-localisation, or the "glocal" paradigm.

The processes of Hellenistic globalisation and localisation, or glocal, are inseparable, and they coexisted, as is evident in many Hellenistic sites, in a continuous state of change and interaction. Thus, the Eastern Mediterranean Hellenistic world emerged as societies adapted and developed Western Greco-Macedonian culture. This new Eastern Hellenistic Greco-Macedonian model was one of many modern ways, and it led to the production of built environments in which Western Hellenism was re-adjusted. Thus, in this way, 
emphasising the cross-cultural artistic and creative pollination that occurred throughout the vast expanse of the Hellenistic world resulted in providing a fruitful ground for the articulation of a worldview that transcended as Hellenistic globalisation.

Thus, in Hellenistic architecture, it is time to evoke the more elaborate facades that show patterns and symbols common to funeral and religious architecture. More analytically, in some cases, such as Ptolemaic Alexandrian tomb architecture, Greco-Macedonian Alexandria constructed these monuments to cater to the local non-Greek interests and curry favour with the Ptolemaic king. In other cases, non-Greeks or those familiar with the Greco-Macedonian style built tombs and buildings in the Greco-Macedonian style in a traditionally local space.

These extensive architectural structures and decoration can shed light on the multicultural identity of their citizens in the context in which they coexist and interact with each other. The paradigm of Alexandria, along with the other Greco-Macedonian poleis, is traditionally considered to have been affected by Hellenisation. It is generally true that Macedonia did not approach Alexandria as a place in need of cultural improvement-Hellenic culture, particularly that of Macedonia and Athens, was praised by the Alexandrians and subjects such as sculpture, drama, poetry, rhetoric, and architectural styles were emulated and studied by much of the Alexandrian elite. This does not mean, however, that Macedonia was exempt from Alexandrian influence. On the contrary, Alexandrians' reaction to Macedonian influence in public ritual spaces was multifaceted. The local non-Greek interest and benefactions shaped the Hellenisation of the city, which can be seen in the ways Alexandria adopted and adapted Greco-Macedonian rule.

Finally, as Satler [59] (p. 22) believes, the co-existence of diverse philosophies is not only possible but necessary. As Hellenistic globalisation resulted from a cross-cultural interaction and synthesis between the courageous sensibleness of the Greco-Macedonian mind and the sensitive, creative Eastern mind and vision of preserving traditional elements and practice, the product provided fruitful ground for an articulation of a transcended worldview. The Hellenistic globalisation model that Alexander employed was quite different from the Roman one and most if not of all the models of globalisations ever since, including, to a certain degree, the model of the current one in which Eastern civilisations, the Orient, were negatively perceived. The Orient is thus presented as decadent, despotic, and unqualified for liberated creative development.

Funding: This research received no external funding.

Acknowledgments: The efforts taken in compiling this research would not have been possible without the kind support of the Hashemite University in Jordan, and previously the support of many individual Greek friends starting with the late Andronicos, M.; Velenis, G.; Koutaridi, M.; Petronotis, A.; Adam-Veleni, P.; Saatsoglou-Paliadeli, Ch.; Drougou, S.; Chrisistomou, P.; Tsigarida, P.; Karamitrou-Mentessidi, G.; Faklaris, P.; Lilibaki-Akamati, M. and Akamatis, I. I want to extend my sincere thanks to all of them.

Conflicts of Interest: The author declares no conflict of interest.

\section{References}

1. Arora, U.P. India and the Hellenistic World. In Proceedings of the Second Hellenistic Studies Workshop Alexandria Proceedings/edited by Kyriakos Savvopoulos, Alexandria Center for Hellenistic Studies. Alexandria, Egypt, 4-11 July 2010; pp. 45-65.

2. Fernandez, D. The Modern Image of Alexander the Great: Alexander in Cinema, Rutgers. Master's Thesis, The State University of New Jersey, Newark, NJ, USA, 2020.

3. Stoneman, R. The Legacy of Alexander in Ancient Philosophy. In Brill's Companion to Alexander the Great; Brill: Leiden, The Netherlands, 2003; p. 325.

4. Pollitt, J.J. Art in the Hellenistic Age; Cambridge University Press: Cambridge, UK, 1986.

5. Aristotle-Alexander the Great. IMDb. IMDb.com, 23 March 1956. Available online: https://www.imdb.com/title/tt0048937/ (accessed on 8 October 2021).

6. Haddad, N. Macedonia, Alexandria, Petra: Tomb Architecture. In Proceedings of the International Congress, Alexander the Great: From Macedonia to the Oikoumene, Veria, Greece, 27-31 May 1998; pp. 161-171. 
7. Shahbazi, S. Irano-Hellenic Notes: 3. Iranians and Alexander. Am. J. Anc. Hist. 2003, 2, 5.

8. Robertson, C.M. Hellenistic History and Culture; Green, P., Ed.; University of California Press: Berkeley, CA, USA, 1993.

9. Fischer-Bovet, C. Towards a translocal elite culture in the Ptolemaic Empire. In Cosmopolitanism and Empire: Universal Rulers, Local Elites and Cultural Integration in the Ancient Near East Mediterranean; Lavan, M., Payne, R., Weisweiler, J., Eds.; Oxford University Press: Oxford, UK, 2016; pp. 103-128.

10. Stek, T.D. Roman imperialism, globalisation and Romanisation in early Roman Italy.Research questions in archaeology and ancient history. Archaeol. Dialogues 2014, 21, 30-40. [CrossRef]

11. Pitts, M.; Versluys, M.J. Globalisation and the Roman World; World History, Connectivity and Material Culture; Cambridge University Press: Cambridge, UK, 2015.

12. Baghos, M. Hellenistic Globalisation and the Metanarrative of the Logos. Mod. Greek Stud. Aust. N. Z. 2017, 23-37. Available online: https: / www.semanticscholar.org/paper/Hellenistic-globalisation-and-the-metanarrative-of-Baghos/e1f80fcf97ab5 $5 \mathrm{c} 6 \mathrm{daffe} 60 \mathrm{dbb} 264 \mathrm{c} 68 \mathrm{c} 4 \mathrm{cf} 62 \mathrm{fb}$ (accessed on 8 October 2021).

13. Assmann, J. Globalization, Universalism, and the Erosion of Cultural Memory. In Originalveröffentlichung Aleida Assmann, Sebastian Conrad (Hg.), Memory in a Global Age. Discourses, Practices and Trajectories, Palgrave Macmillan Memory Studies; Palgrave Macmillan: New York, NY, USA, 2010; pp. 121-137.

14. Coleman, M.D. Cultural Identity in the Roman Near East: An Historiographical Exercise. Ph.D. Thesis, Victoria University of Wellington, Wellington, New Zealand, 2013.

15. Gruen, E.S. Jews and Greeks. In A companion to the Hellenistic World; Erskine, A., Ed.; Blackwell: Malden, MA, USA, 2003; pp. 264-279.

16. Stavrou, D. The Gymnasium in the Hellenistic East: Motives, Divergences, and Networks of Contracts. Ph.D. Thesis, University of Leicester, Leicester, UK, 2016.

17. Grimal, P. Hellenism and the Rise of Rome; Delacorte Press: New York, NY, USA, 1968.

18. Chamoux, F. Hellenistic Civilisation; Blackwell: Malden, MA, USA; Oxford, UK, 2003.

19. Haddad, N. Aspects of the Particularity and Creativity of the Nabataean Architectural Culture during the Late Hellenistic and Roman period. In Proceedings of the First International Conference of the Nabataean Culture, Petra, Jordan, 5-8 May 2012; In Studies on the Nabataean Culture I, Publication of the Deanship of Scientific Research. The University of Jordan: Amman, Jordan, 2013; pp. 103-117.

20. Haddad, N. The Macedonian Tomb Facade Formation and its Significant Role and Critical Stage for the Development of Hellenistic and Late Classical Facade Morphology. In Proceedings of the 16th Annual International Conference on History \& Archaeology: From Ancient to Modern, Athens, Greece, 2-5 July 2018; Atiner's Conference Paper Series, No: HIS2018-2561. Athens Institute for Education and Research: Athens, Jordan, 2018; pp. 1-32.

21. Ward, W.D. Orientalism and the Study of the Pre-modern Middle East. Athens J. Mediterr. Stud. 2017, 4, 7-18. [CrossRef]

22. Strootman, R. The Seleukid Empire between Orientalism and Hellenocentrism: Writing the History of Iran in the Third and Second Centuries BCE. Iran. Stud. 2013, 11, 17-35.

23. Edward, S. Orientalism; Vintage Books: New York, NY, USA, 1978.

24. Gills, B. Whither Democracy? Globalisation and the 'New Hellenism'. In Globalization and the South; Thomas, C., Wilkin, P., Eds.; International Political Economy Series; Palgrave Macmillan: London, UK, 1997.

25. Bintliff, J. The Hellenistic To Roman Mediterranean: A Proto-Capitalist Revolution? Econ. Archaeol. Struct. Perform. Eur. Archaeol. 2013, 1, 285-292.

26. Davies, J.K. Hellenistic Economies. In The Cambridge Companion to the Hellenistic World; Bugh, G.R., Ed.; Cambridge University Press: Cambridge, UK, 2006; pp. 73-92.

27. Morris, M. Colors of Conquest: A Regional Survey of Hellenistic Painting. Berkeley Undergrad. J. Class. 2016, 4, 1-14.

28. Farrington, B. Greek Science; Penguin Books: Baltimore, MD, USA, 1961.

29. Zelnick-Abramovitz, R. Whose Grave Is This? The status of Grave Plots in Ancient Greece. Dike Riv. Stor. Dirit. Greco Ellenistico 2015, 18, 51-95.

30. Rizakis, A.D. Les colonies Romaines des côtes occidentales Grècques. Populations et territoires. Dialogues D'histoire Anc. 1996, 22, 255-324. [CrossRef]

31. Adam-Veleni, P.; Poulaki, E.; Tzanavari, K. Ancient Country Houses on Modern Roads. Central Macedonia; The Archaeological Receipts Fund: Athens, Greece, 2003.

32. Strootman, R. The dawning of a golden age: Images of peace and abundance in Alexandrian court poetry in the context of Ptolemaic imperial ideology. In Hellenistic Poetry in Context. Tenth International Workshop on Hellenistic Poetry; Wakker, G.C., Regtuit, R.F., Harder, A., Eds.; Peeters: Leuven, Belgium, 2014; pp. 325-341.

33. Strootman, R. The Hellenistic Royal Court. Court Culture, Ceremonial and Ideology in Greece, Egypt and the Near East, 336-30 BCE. Ph.D. Thesis, Utrecht University, Utrecht, The Netherlands, 2007. Available online: https://dspace.library.uu.nl/bitstream/ handle/1874/22154/index.htm (accessed on 8 October 2021).

34. Küçükkalay, A.M. İktisadi Düşünce Tarihi; Beta: İstanbul, Turkey, 2010.

35. Attema, P.; Burgers, G.J.; Van, M.L. Regional Pathways to Complexity: Settlement and Land-Use Dynamics in Early Italy from the Bronze Age to the Republican Period; Amsterdam University Press: Amsterdam, The Netherlands, 2010. [CrossRef] 
36. Rodríguez-Antón, A.; Belmonte, J.A.; González-García, A.C. Romans in the Near East: The Orientation of Roman Settlements in Present-Day Jordan. Mediterr. Archaeol. Archaeom. 2016, 16, 153-160.

37. Archibald, Z. Ancient Economies of the Northern Aegean: Fifth to First Centuries BC; Oxford University Press: Oxford, UK, 2013.

38. Billows, R. Cities. In A Companion to the Hellenistic World; Erskine, A., Ed.; Blackwell Publishing Ltd.: Oxford, UK, 2003; pp. 196-215.

39. Palagia, O. The Impact of Alexander the Great in the Art of Central Asia. Alexander Roman. Persia East 2012, 15, $369-382$.

40. Seignobos, C. Avrupa Kavimlerinin Mukayeseli Tarihi, (çev. Yalçın, Hüseyi); B Kanaat Kitabevi: İstanbul, Turkey, 1939.

41. Paffen, C. Minting IDeas: Civic Identity and Relationship with Rome in Roman Provincial Coinage. Master's Thesis, University of Leiden, Leiden, The Netherlands, 2018. Available online: https://studenttheses.universiteitleiden.nl/access/item\%3A2660014 / view (accessed on 8 October 2021).

42. Naccache, A.F. Empire of the Amorites Revisited. In Proceedings of the International Symposium on Syria and the Ancient near East 3000-300 BC; Ismail, F., Ed.; University of Aleppo Publications: Aleppo, Suriye, 1996; pp. $29-51$.

43. Cunningham, J. The Role of Learning Institutions in Ptolemaic Alexandria. Master's Thesis, Western Washington University WWU Graduate School Collection, 2010. Available online: https:/ / cedar.wwu.edu/wwuet/52 (accessed on 8 October 2021).

44. Strootman, R. Hellenism and Persianism in Iran: Culture and Empire after Alexander the Great; Samuel Jordan Center for Persian Studies and Culture, University of California: Irvine, CA, USA, 2020; No. 7.

45. Bowersock, G.W. Hellenism in Late Antiquity; Cambridge University Press: Cambridge, UK, 1990.

46. Manning, J.G. Cross-Cultural Communication in Egypt. In Mercury's Wings. Exploring Modes of Communication in the Ancient World; Richard, J.A., Ed.; Talbert and Fred S. Naiden: Oxford, UK, 2017. [CrossRef]

47. Andrade, N. Syrian Identity in the Greco-Roman World; Cambridge University Press: Cambridge, UK, 2013.

48. Butcher, K. Roman Syria and the Near East; The J. Paul Getty Museum: Los Angeles, CA, USA, 2003.

49. Nezhad, A.A. A New Insight to the Persis Kings (Frataraka). Int. J. Archaeol. 2018, 6, 37. [CrossRef]

50. Miller, S.G. The Tomb of Lyson and Kalliklis: A Painted Macedonian Tomb; Mainz am Rhein: Mainz, Germany, 1993.

51. Curtis, V.S. The Iranian revival in the Parthian period. In The Age of the Parthians; The Idea of Iran; Curtis, V.S., Stewart, S., Eds.; Bloomsbury Publishing: London, UK; New York, NY, USA, 2007; Volume 2, pp. 7-25.

52. Thonemann, P.A. The Hellenistic World: Using Coins as Sources; Cambridge University Press: Cambridge, UK, 2015.

53. Burnett, A. The Augustan Revolution Seen from the Mints of the Provinces. J. Rom. Stud. 2011, 101, 1-30. [CrossRef]

54. Papagerogiadou-Bani, H. The Numismatic Iconography of the Roman Colonies in Greece: Local Spirit and the Expression of Imperial Policy; ME $\Lambda$ ETHMATA 39; Papagerogiadou-Bani, H., Ed.; AJA Open Access: Athens, Greece, 2004.

55. Upinder, S. A History of Ancient and Early Medieval India: From the Stone Age to the 12th Century; Pearson \& Longman: New Delhi, India, 2009; p. 374.

56. Katsari, C. The Roman Monetary System. The Eastern Provinces from the First to the Third Century A.D.; Cambridge University Press: Cambridge, UK, 2011.

57. Burnett Amandry, M.; Ripolles, P.P. Roman Provincial Coinage; British Museum Press: London, UK, 2003 ; Volume 1.

58. Mahgoub, Y. Globalization and the built environment in Kuwait. Habitat Int. 2004, 28, 505-519. [CrossRef]

59. Satler, G. The Architecture of Frank Lloyd Wright: A Global View. J. Arch. Educ. 1999, 53, 15-24. [CrossRef]

60. El-sheshtawy, Y.; Mohsen, A.N. Sustainable Urban Development in an Age of Globalization: Towards a Co-Existence Model in Dubai, Uae. In Metropolis 2000-Which Perspectives? Cities, Social Life and Sustainable Development: IAPS 16 Conference Proceedings on CD-Rom; IAPS: Paris, France, 2000.

61. Lefaivre, L.; Tzonis, A. Critical Regionalism: Architecture and Identity in a Globalised World; Prestel Pub: New York, NY, USA, 2003.

62. Adam, R. Globalisation and architecture: The challenges of globalisation are relentlessly shaping architecture's relationship with society and culture. In The Architectural Review; EMAP Publishing Limited: London, UK, 2008; Volume 223, pp. 74-77.

63. Eldemery, I.M. Globalization Challenges in Architecture. J. Archit. Plan. Res. 2009, 26, 343-354.

64. Licka, L.; Roehr, D. Globalisation and landscape architecture. Landsc. J. 2008, 27, 319-332.

65. Hewitt, R.R. Globalization and Landscape Architecture. SAGE Open 2014, 4. [CrossRef]

66. Nalimova, N. The Origin and Meaning of Floral Imagery in the Monumental Art of Macedonia (4th-3rd centuries B.C.). In Macedonian-Roman-Byzantine: The Art of Northern Greece from Antiquity to the Middle Ages: Proceedings of the Conference; Izdatel'stvo "KDU": Moscow, Russia, 2017; pp. 13-35.

67. Smith, R.R.R. Hellenistic Sculpture: A Handbook; Thames \& Hudson, Limited: London, UK, 1991.

68. Licenziati, F. The Techniques and Materials of Hellenistic Mosaics with a Special Focus on the Vitreous Materials of the Mosaics from Delos (Greece), the Narnia Project Integrating Approaches to Ancient Material Studies; Kassianidou, V.V., Dikomitou-Eliadou, M., Eds.; NARNIA Project and the Archaeological Research Unit, University of Cyprus: Nicosia, Cyprus, 2014; pp. 172-182.

69. Bounni, A. Couronnement des sanctuaires du Proche-Orient hellénistique et romain: Origine et développement du merlon. Topoi 1999, 9, 507-525. [CrossRef]

70. Kosmin, P.J. The Land of the Elephant Kings: Space, Territory, and Ideology in the Seleucid Empire. Class. World 2016, 109, 275-277.

71. Haddad, N. Doors and Windows in Hellenistic and Roman Greece. Ph. D. Thesis, School of Architecture, Aristotle University of Thessaloniki, Thessaloniki, Greece, 1995.

72. Finley, M.I. Atlas of Classical Archaeology, 1st ed.; McGraw-Hill: New York, NY, USA; London, UK, 1977. 
73. Ion, S.A. Identity and Material Culture in Seleucid Jebel Khalid. Ph.D. Thesis, University of Cincinnati, Cincinnati, OH, USA, 2017.

74. Khouri, R. Petra: A Guide to the Capital of the Nabataeans; Longman: New York, NY, USA; London, UK, 1986.

75. Barghouti, A.N. Urbanisation of Palestine and Jordan in Hellenistic and Roman Times; Shaj, I., Ed.; Brill: Leiden, The Netherlands, 1982; pp. 209-229.

76. Wright, T. Early Travels in Palestine, 1st ed.; H. G. Bohn: New York, NY, USA; London, UK, 1848.

77. Stone, S.C.; McKenzie, J. The Architecture of Petra. Am. J. Archaeol. 1996, 97, 369. [CrossRef]

78. Savopolous, K. Alexandria in Aegypto, The Use And Meaning Of Egyptian Elements In Hellenistic And Roman Alexandria Ideology: Culture, Identity, and Public Life. Ph.D. Thesis, Leiden University, Leiden, The Netherlands, 2011.

79. Bianchi, R.S.; Venit, M.S. Monumental Tombs of Ancient Alexandria. The Theater of the Dead. J. Am. Res. Cent. Egypt 2003, 40, 191. [CrossRef]

80. Allen, B.K. Mawr Classical Review. Available online: https://bmcr.brynmawr.edu/2003/2003.02.12/ (accessed on 8 October 2021).

81. Çinar, A. The imagined community as urban reality: The making of Ankara. In Urban Imaginaries: Locating the Modern City; Çinar, A., Bender, T., Eds.; University of Minnesota Press: Minneapolis, MN, USA, 2007; pp. 151-181.

82. Haddad, N.A.; Sakr, Y.M.; Fakhoury, L.A. Investigating Gottfried Semper's Symbolic Approach to the Surface Design in Hellenistic Architecture: The Case of the Macedonian Tombs. Mediterr. Archaeol. Archaeom. 2019, 19, 1-16. [CrossRef] 